Research Paper

\title{
GERMINATION TEST FOR DIATOMS FROM COASTAL ESTUARY SEDIMENT
}

\author{
Bach Quang Dung ${ }^{1}$
}

\section{ARTICLE HISTORY}

Received: October 08, 2019 Accepted: November 12, 2019

Publish on: December 25, 2019

\begin{abstract}
Planktonic diatoms produce resting stages that survive in the sediment and allow species persistence over periods in which vegetative growth does not occur. Sediments from coastal estuary in the Mokpo Harbour, Korea were took and investigated. Diatom germination tests from sediment were carried out in laboratory. Diatom cells were identified by microscope based on standard method. This study provided more understanding of diatom germination from in situ sediment, seasonal condition as nutrient, light, moonson might also affect and decide significantly phytoplankton growth and bloom in coast. The study is very useful for investigation about plankton dynamic, food chain in coastal areas in general.
\end{abstract}

Keywords: Diatom, Germination, Sediment, Coastal estuary.

\section{Introduction}

Diatoms were an important component to phytoplankton communities in coastal estuarine system (Sarthou et al., 2005; Tsuda et al., 2005; Wysocki et al., 2006; Gameiro et al., 2007). Diatoms account for $20-25 \%$ of the total global primary production (Werner, 1977), and the majority of variability in phytoplankton biomass in coastal waters is due to changes in the abun- dance of chain-forming diatoms (Moses and Wheeler, 2004; Whitney et al., 2005; Shipe et al., 2006). Phytoplankton size structure or phytoplankton taxa, especially diatoms were impacted by alterations of surrounding environmental conditions (Sin et al., 2000; Domingues et al., 2005; Shimada et al., 2006; Popovich and Marcovecchio, 2008). In the coastal aquatic food web, phytoplankton in terms of primary producers has relationships with various grazers (Semeneh et al., 1998; Froneman et al., 2004). Diatoms, especially, have played an important role in coastal microbial food web dynamics (Garrison et al., 2000; Rousseau et al., 2000). For instance, mesozooplankton such as copepods mostly feed on diatoms during diatom bloom (Paffenhöfer, 2002; Vargas and González, 2004; Schultes et al., 2006). In this context, it is important to examine diatom dynamics for better understanding of the estuarine phytoplankton dynamics.

Recently, the human activities such as industry and embankment construction and increasing population density have impacted marine ecosystems. The embankment constructions significantly restricted the circulation of water masses and changed the surrounding properties such as water temperature and turbidity (YSLME, 2001). A study of diatom germination from sediment can provides useful information on characteristics of phytoplankton communities and the microbial aquatic food web since diatom

\section{BACH QUANG DUNG}

dungmmu05@gmail.com

${ }^{1}$ Vietnam Journal of Hydrometeorology, Hanoi, Vietnam 
dynamics and related parameters have not been reported. In this study, we investigated the importance of diatom germination from coastal estuary sediment under different conditions in laboratory.

\section{Materials and Methods}

\subsection{Sediment collection}

Sediments were collected as grab samples at depth $10 \mathrm{~m}$ from an estuary immediately adjacent to an embankment in the Mokpo Harbour, Korea. Seawater was also collected from the site. The sediment and seawater were kept at $5^{\circ} \mathrm{C}$ during transportation and stored in the dark prior to use.

\subsection{Experimental design}

In situ seawater was filtered through PTFE $0.45 \mu \mathrm{m}$ membrane (Fig. 1b). Fritz $\mathrm{F} / 2$ (solution A, solution B, Si) algae food was used to enhance phytoplankton germination. Diatoms from sampled sediment were inoculated into growth bottles ( $2 \mathrm{~g}$ wet sediment $+1 \mathrm{~L}$ filtered sea water) and resuspended. Nutrient to grow diatoms was added to a bottle (Adding nutrients: solution $\mathrm{A}+$ solution $\mathrm{B}+\mathrm{Si}$ ) and another bottle was not (Non Adding nutrients) (Fig. 1c). Both of bottles were incubated in Labtech ${ }^{\circledR}$ incubator (temperature $20^{\circ} \mathrm{C}$, light

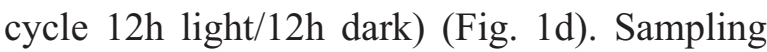
schedule arranged after day $1,3,6,7,8,9,10,11$, $12,13,14,15$ during incubation period.

\subsection{Diatom identification}

$10 \mathrm{ml}$ water samples from each incubation bottle were daily taken and insert into $15 \mathrm{ml}$ test tube containing 3 drops Lugol's solution (I2 final concentration: $250 \mathrm{mg} \mathrm{L}-1)$. Phytoplankton samples were stored in the laboratory at least $48 \mathrm{~h}$ for settling down. After the storage, samples were slowly decanted to $8 \mathrm{ml}$ surface water. The remaining $2 \mathrm{ml}$ sample was mixed and $1 \mathrm{ml}$ was taken to drop into a Sedgwick-Rafter counting chamber $(50 \times 20 \times 1 \mathrm{~mm})$. Diatom cells were identified (Tomas, 1997) and 200 chambers were counted by using Axioskop ${ }^{\circledR} 2$ MAT (ZEISS).
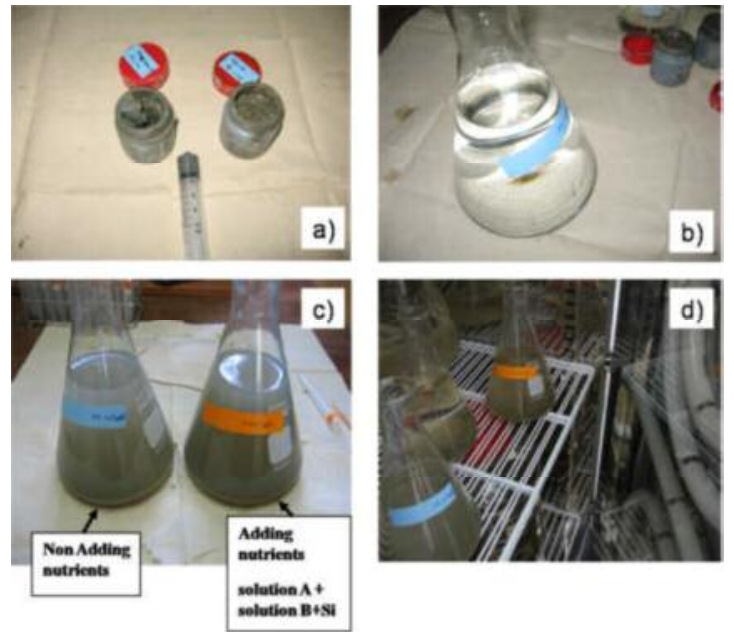

Fig. 1. Experimental setup for diatom germination test: a) wet sediment collection; b) filtered sea water preparation; c) Inoculated ( $2 \mathrm{~g}$ wet sediment+ $1 \mathrm{~L}$ filtered sea water), resuspended, nutrient added; d) incubation in Labtech ${ }^{\circledR}$ incubator (temperature $20^{\circ} \mathrm{C}$, light cycle $12 \mathrm{~h}$ light/12h dark).

\section{Results}

\subsection{Vegetative diatom from resting stage}

Many planktonic diatoms produce resting stages that survive in the sediment and allow species persistence over periods in which vegetative growth does not occur. Diatom benthic stage is evident, we used surface sediments from the Mokpo Harbour, Korea where diatom in resting stages to seed as source for this study. The diatom species recorded to germinate from sediments into seawater, showing that the formation of resting stages is a widespread life in coastal areas. The most abundant taxa recorded in the plankton were several species of the genera Cylindrotheca, Pseudonitzschia Skeletonema, Thalassiosira, Navicula, and Chaetoceros (Fig. 2 and Fig. 3). Peaks of growth stage from resting stage were generally recorded during incubation process in laboratory.

Fig. 4 shown that variation of vegetative cells in surface water samples and of viable resting stages in sediment was represented. The most abundant species in the incubated sediment samples were Cylindrotheca closterium, Pseudo- 
nitzschia seriata, Navicula distans, Navicula directa, Skeletonema costatum, Thalassiosira rotula, Chaetoceros socialis. Cylindrotheca closterium reached the highest cell concentrations in both incubated bottles. Nutrient addition was a important role for growth of diatoms from resting stages. Peaks of diatom cell appeared 2 times during 15 days incubation with nutrient addition, however there was one low peak in non-adding nutrient condition (Fig. 4). Mixing condition was also key effect for the diatom bloom.

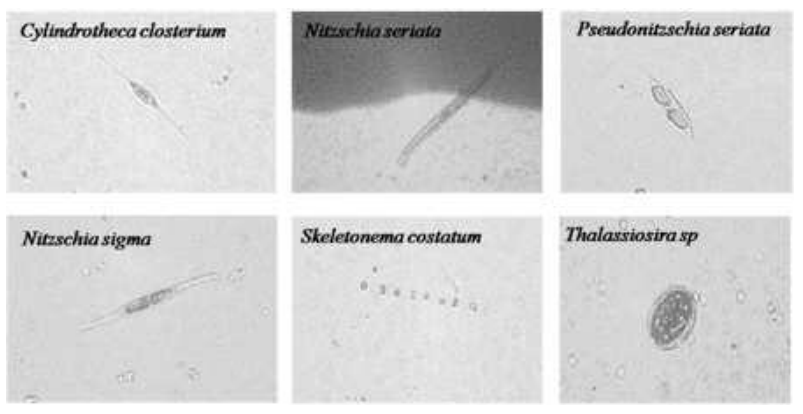

Fig. 2. Diatom dominant species taken by microscopy and software in laboratory germination test.

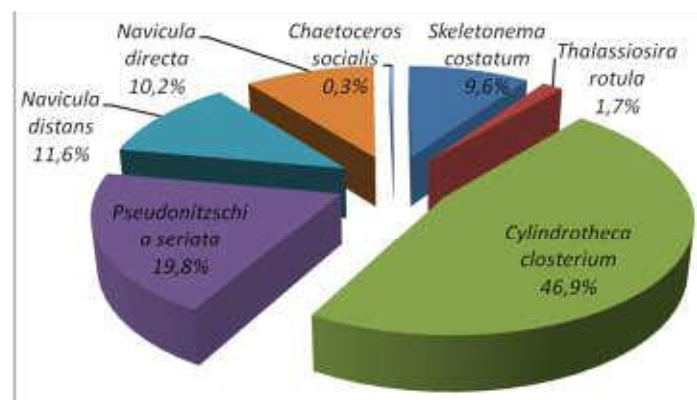

Fig. 3. Component of diatom dominant species was observed after 7 day incubated

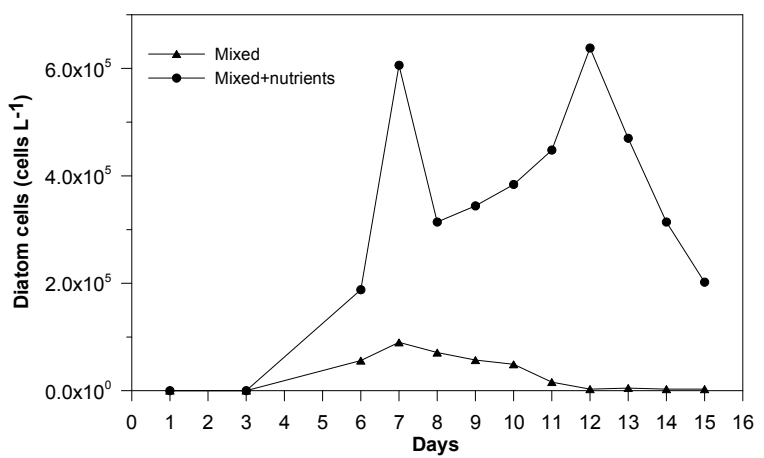

Fig. 4. Germination of diatom in field seawater from sediment with laboratory incubation conditions: mixed and mixed + nutrients

\subsection{Discussion}

Temporal variations of physio-chemical factors can influence the abundance, biomass contribution and dominant genera of diatoms in coastal estuaries (Pratt, 1965; Goffart et al., 2002; Madhu et al., 2007). In coasts and estuaries, spring diatom blooms were developed by: (1) germination increase from diatom resting stage in sediment due to well mixing, (2) increase of water column irradiance (Pitcher, 1990; Iriarte and Purdie, 2004; Ishikawa and Furuya, 2004; Gloria et al., 2009). According to Andersson et al. (1994), diatoms were dominant concomitant with netphytoplankton even temperature was lower than $10 \mathrm{oC}$. Increase of wind speed during February-March can resuspend sediment in shallow water such can force germination of diatoms from resting stage in sediment. Diatom genera such as Thalassiosira spp., Skeletonema costatum and Chaetoceros spp. were dominant during spring both in the sediments and water column (Zhang et al., 2010). These species were also listed by Ishikawa and Furuya (2004) whereas diatoms having resting stages in the sediments. The results indicate that the spring bloom may be characterized by diatom species adapted to the physio-chemical properties of cold season and wind forced mixing in the coastal estuary.

When water temperature increased diatom bloom could exhaust ambient nutrients from the water for growth. According to Wong et al. (2002), nutrient depletion occurred due to enhancement of diatom production. The nutrient depletion and temperature increase may be catalysts for the shift in size structure of phytoplankton to nanophytoplankton. In case of diatoms, photosynthesis relates to cell size and the smallest cells have the highest growth rates due to high harvesting light and high nutrient uptake; they can adapt to low nutrient concentrations (Sarthou et al., 2005).

In the estuary, the embankment restricted freshwater discharge during dry season (winter-spring). Wind mixing increased in early 
spring due to moonson caused resuspension of the sediment in shallow water depth. The scattered freshwater discharge may supply better nutrient such as silicate for diatom growth at the upper region in early spring. This suggests that diatoms favor at the upper region with resuspended water and nutrient input during early spring. This may be due to the dramatic increase of freshwater discharge from embankments during the wet season that directly impacted the growth and abundance of diatoms by altering physical properties such as low salinity, short residence time at the upper region (Mallin et al., 1991; Madariaga et al., 1992; Muylaert and Sabbe, 1999).

All species found in the sediments were components of the plankton. Resting stage species composition in the sediments was related to historical records of planktonic diatom composition in the water (Roberta et al., 2017). However, several species vegetative cells those were important components of the plankton did not germinate from bottom sediments: Cylindrotheca closterium, Pseudonitzschia seriata, Navicula distans, Navicula directa. Their absence may be a result of (1) poor viability such as nutrients, (2) unsuitable growth conditions for this particular population such as light and mixing by moonson, (3) competition with other diatoms in the cultures, (4) relying on other mechanisms than benthic resting stages to repopulate surface waters, or (5) too low density (Zhang et al., 2010)

The temporal variability of species specific diatom resting stage abundance in surface sediments of a coastal site in comparison with the abundances of vegetative stages in the plankton (Tatiana and Tatiana, 2009; Marina et al., 2013). In this study, germination of individual species appears to occur whenever sediments were exposed to light, mixing and nutrients. The lack of a connection from benthos to plankton points to the complex relationship among the key diatom species was not clear yet, but could also be due to the intrinsic limitations.

Top-down control of diatoms by mesozooplankton during spring bloom was documented in the previous studies (Kuuppo et al., 1998; Hansen et al., 2000; Bode et al., 2005). Diatoms also highly contributed to netphytoplankton in early spring. Therefore, the species may be suitable for grazing by mesozooplankton.

\section{Conclusion}

Diatoms staying in resting stages in coastal sediment are phenomenal. Nutrient enrichment can enhance diatom germination faster than normal condition. Nutrient has driven the abundant of diatom species in coastal estuary. Size-structure of planktonic diatoms was affected highly by nutrient in coastal water. Mixing condition is very important for germination of diatom. This explained that diatom always bloomed during windy season (early spring) caused resuspended shallow water in South Korea coasts. Understanding of diatom germination from in situ sediment is significant to investigate ecosystem in coastal estuary. Seasonal condition such as nutrient, light, moonson could also affect and decide phytoplankton growth and bloom in coast. The study is very useful for investigation about plankton dynamic, food chain in coastal areas in general.

\section{Acknowledgements}

We thank Microbial Ecology Laboratory, Mokpo National Maritime University for supporting to do these experiments. The author thanks reviewers for their constructive comments. 


\section{References}

1. Andersson, A., Haecky, P., Hagström, Å., 1994. Effect of temperature and light on the growth of micro- nano- and pico-plankton: impact on algal succession. Marine Biology, 120: 511-520.

2. Bode, A., Álvarez-Ossorio, M.T., González, N., Lorenzo, J., Rodríguez, C., Varela, M., Varela, M.M., 2005. Seasonal variability of plankton blooms in the Ria de Ferrol (NW Spain): II. Plankton abundance, composition and biomass. Estuarine, Coastal and Shelf Science, 63: 285-300.

3. Domingues, R.B., Barbosa, A., Galvão, H., 2005. Nutrients, light and phytoplankton succession in a temperate estuary (the Guadiana, south-western Iberia). Estuarine, Coastal and Shelf Science, 64: 249-260.

4. Gameiro, C., Cartaxana, P., Brotas, V., 2007. Environmental drivers of phytoplankton distribution and composition in Tagus Estuary, Portugal. Estuarine, Coastal and Shelf Science, 75: 21-34.

5. Garrison, D.L., Gowing, M.M., Hughes, M.P., Campbell, L., Caron, D.A., Dennett, M.R., Shalapyonok, A., Olson, R.J., Landry, M.R., Brown, S.L., Liu, H.-B., Azam, F., Steward, G.F., Ducklow, H.W., Smith, D.C., 2000. Microbial food web structure in the Arabian Sea: a US JGOFS study. Deep Sea Research II, 47: 13871422.

6. Gloria, E.S., Diana, S., Marina, M., Raffaele, S., Carina, B.L., 2009. Germination of resting stages of diatoms and dinoflagellates in marine sediments from two upwelling areas of Chile. Gayana Bot., 66(2): 293-255.

7. Goffart, A., Hecq, J.H., Legendre, L., 2002. Changes in the development of the winter-spring phytoplankton bloom in the Bay of Calvi (NW Mediterranean) over the last two decades: a response to changing climate?. Marine Ecology Progress Series, 236: 45-60.

8. Hansen, B.W., Hygum, B.H., Brozek, M., Jensen, F., Rey, C., 2000. Food web interactions in a Calanus finmarchicus dominated pelagic ecosystem-a mesocosm study. Journal of Plankton Research, 22: 569-588.

9. Iriarte, A., Purdie, D.A., 2004. Factors controlling the timing of major spring bloom events in an UK south coast estuary. Estuarine, Coastal and Shelf Science, 61: 679-690.

10. Ishikawa, A., Furuya, K., 2004. The role of diatom resting stages in the onset of the spring bloom in the East China Sea. Marine Biology, 145: 633-639.

11. Kuuppo, P., Autio, R., Kuosa, H., Setälä, O., Tanskanen, S., 1998. Nitrogen, silicate and zooplankton control of the planktonic food-web in spring. Estuarine, Coastal and Shelf Science, 46: 65-75.

12. Madariaga, I.D., González-Azpiri, L., Villate, F., Orive, E., 1992. Plankton responses to hydrological changes induced by Freshets in a shallow mesotidal estuary. Estuarine, Coastal and Shelf Science, 35: 425-434.

13. Madhu, N.V., Jyothibabu, R., Balachandran, K.K., Honey, U.K., Martin, G.D., Vijay, J.G., Shiyas, C.A., Gupta, G.V.M., Achuthankutty, C.T., 2007. Monsoonal impact on planktonic standing stock and abundance in a tropical estuary (Cochin backwaters - India). Estuarine, Coastal and Shelf Science, 73: 54-64.

14. Mallin, M.A., Paerl, H.W., Rudek, J., 1991. Seasonal phytoplankton composition, productivity and biomass in the Neuse River estuary, North Carolina. Estuarine, Coastal and Shelf Science, 32: 609-623.

15. Marina, M., Carmen D.P., Diana S., Francesca M., Adriana Z.,. 2013. Diversity and germination patterns of diatom resting stages at a coastal Mediterranean site. Marine Ecology Progress Series, 484: 79-95.

16. Moses, W.C., Wheeler, P.A., 2004. Wheeler seasonal and across-shelf trends of the phytoplankton community of the Oregon coastal environment. Northeast Pacific GLOBEC Long Term Observation Project, College of Oceanic and Atmospheric Sciences Oregon State University. 
17. Muylaert, K., Sabbe, K., 1999. Spring phytoplankton assemblages in and around the maximum turbidity zone of the estuaries of the Elbe (Germany), the Schelde (Belgium/The Netherlands) and the Gironde (France). Journal of Marine Systems, 22: 133-149.

18. Paffenhöfer, G.A., 2002. An assessment of the effects of diatoms on planktonic copepods. Marine Ecology Progress Series, 227: 305-310.

19. Pitcher, G.C., 1990. Phytoplankton seed populations of the Cape Peninsula upwelling plume, with particular reference to resting spores of Chaetoceros (bacillariophyceae) and their role in seeding upwelling waters. Estuarine, Coastal and Shelf Science, 31: 283-301.

20. Popovich, C.A., Marcovecchio, J.E., 2008. Spatial and temporal variability of phytoplankton and environmental factors in a temperate estuary of South America (Atlantic coast, Argentina). Continental Shelf Research, 28: 236244.

21. Pratt, D.M., 1965. The winter-spring diatom flowering in Narragansett Bay. Limnology and Oceanography 10, 173-184.

22. Roberta, P., Diana, S., Carina, B.L., Maria, P.T., Adriana, Z., Marina, M., 2017. Diatom Resting Stages in Surface Sediments: A Pilot Study Comparing Next Generation Sequencing and Serial Dilution Cultures. Cryptogamie, Algologie, 38(1): 31-46.

23. Rousseau, V., Becquevort, S., Parent, J.Y., Gasparini, S., Daro, M.-H., Tackx, M., Lancelot, C., 2000. Trophic efficiency of the planktonic food web in a coastal ecosystem dominated by Phaeocystis colonies. Journal of Sea Research, 43: 357-372.

24. Sarthou, G., Timmermans, K. R., Blain, S., Tréguer, P., 2005. Growth physiology and fate of diatoms in the ocean: a review. Journal of Sea Research, 53: 25-42.

25. Schultes, S., Verity, P.G., Bathmann, U., 2006. Copepod grazing during an iron-induced diatom bloom in the Antarctic Circumpolar Current (EisenEx): I. Feeding patterns and grazing impact on prey populations. Journal of Experi- mental Marine Biology and Ecology, 338: 16-34.

26. Semeneh, M., Dehairs, F., Elskens, M., Baumann, M.E.M., Kopczynska, E.E., Lancelot, C., Goeyens, L., 1998. Nitrogen uptake regime and phytoplankton community structure in the Atlantic and Indian sectors of the Southern Ocean. Journal of Marine Systems, 17: 159-177.

27. Shimada, C., Tanaka, Y., Tanimura, Y., 2006. Seasonal variation in skeletal silicification of Neodenticula seminae, a marine planktonic diatom: Sediment trap experiments in the NW Pacific Ocean (1997-2001). Marine Micropaleontology, 60: 130-144.

28. Shipe, R.F., Curtaz, J., Subramaniam, A., Carpenter, E.J., Capone, D.G., 2006. Diatom biomass and productivity in oceanic and plumeinfluenced waters of the western tropical Atlantic ocean. Deep Sea Research I, 53: 1320-1334.

29. Sin, Y., Wetzel, R.L., Anderson, I.C., 2000. Seasonal variations of size-fractionated phytoplankton along the salinity gradient in the York River estuary, Virginia (USA). Journal of Plankton Research, 22: 1945-1960.

30. Tatiana, Y.O., Tatiana V.M., 2009. Resting stages of microalgae in recent marine sediments of Peter the Great Bay, Sea of Japan. Russian Journal of Marine Biology, 35(4): 313322.

31. Tsuda, A., Kiyosawa, H., Kuwata, A., Mochizuki, M., Shiga, N., Saito, H., Chiba, S., Imai, K., Nishioka, J., Ono, T., 2005. Responses of diatoms to iron-enrichment (SEEDS) in the western subarctic Pacific, temporal and spatial comparisons. Progress in Oceanography, 64: 189-205.

32. Werner, D. (Editor), 1977. The Biology of Diatoms (Botanical Monographs). Vol. 13. University of California Press, pp. 498.

33. Whitney, F.A., Crawford, W.R., Harrison, P.J., 2005. Physical processes that enhance nutrient transport and primary productivity in the coastal and open ocean of the subarctic NE Pacific. Deep Sea Research II, 52: 681-706.

34. Wong, C.S., Waser, N.A.D., Nojiri, Y., Whitney, F.A., Page, J.S., Zeng, J., 2002. Sea- 
sonal cycles of nutrients and dissolved inorganic carbon at high and mid latitudes in the North Pacific Ocean during the Skaugran cruises: determination of new production and nutrient uptake ratios. Deep Sea Research II, 49: 5317-5338.

35. Wysocki, L.A., Bianchi, T.S., Powell, R.T., Reuss, N., 2006. Spatial variability in the coupling of organic carbon, nutrients, and phytoplankton pigments in surface waters and sediments of the Mississippi River plume. Estuarine, Coastal and Shelf Science, 69: 47-63.
36. Vargas, C.A., González, H.E., 2004. Plankton community structure and carbon cycling in a coastal upwelling system. I. Bacteria, microprotozoans and phytoplankton in the diet of copepods and appendicularians. Aquatic Microbial Ecology, 34: 151-164.

37. Zhang, Y., Lu, S., Zhang, C., Gao, Y., 2010. Distribution and germination of viable diatom resting stage cells in sediments of the East China Sea. Acta Oceanol. Sin., 29(5): 121-128. 